such as dizzy spells, syncope, breathlessness, impaired exercise capacity, and postural hypotension. These symptoms may constitute the "pacemaker syndrome," which once recognised is readily treated.

The syndrome results from atrial contraction occurring during ventricular systole and is a consequence of ventricular pacing. The atria contract against closed atrioventricular valves and produce raised mean pressures in the right and left atria with reduced cardiac output and blood pressure. ${ }^{23}$ The pacemaker syndrome occurs when retrograde atrioventricular conduction is intact and conduction spreads from the paced ventricles to the atria generally through the atrioventricular node; this may happen even when antegrade conduction is blocked. Ventricular pacing competing with sinus rhythm may be similarly symptomatic. ${ }^{45}$ Dual chamber pacing, in which pacing and sensing occur in both the atrium and ventricle, is rarely associated with the pacemaker syndrome because the physiological relation of atrial contraction preceding ventricular contraction is maintained. ${ }^{6}$

Patients with pacemaker syndrome complain of syncope or near syncope, dizziness, chest pain, fatigue, breathlessness, palpitations, and neck pulsations or pressure. Examination may show cannon waves in the jugular venous pulse or palpable liver pulsations. The diagnosis is made by observing or reproducing the adverse haemodynamic effects, signs, and symptoms during ventricular pacing. ${ }^{457}$

Though the incidence of this symptomatic pacemaker syndrome is low, many "asymptomatic" patients have felt better with dual chamber pacing when this has been compared with ventricular pacing by within patient randomised control studies..$^{8-12}$ This is mainly because sequential atrioventricular contraction is restored.

Up to a fifth of patients with preserved retrograde atrioventricular conduction develop symptoms suggestive of the pacemaker syndrome. ${ }^{5}$ Retrograde conduction is present in $40 \%$ of patients with complete antegrade atrioventricular block and $90 \%$ of patients with normal atrioventricular conduction who have the sick sinus or carotid sinus syndromes. ${ }^{13}$ Therefore atrial or dual chamber pacing is best for patients with the sick sinus syndrome ${ }^{11}$ and dual chamber pacing for those with the carotid sinus syndrome. ${ }^{14} 15$

Symptoms of the pacemaker syndrome may be reduced by reprogramming a ventricular pacemaker so that competition between paced and sinus rhythm is minimised by adding rate hysteresis such that pacing starts only after a pause substantially longer than the pacing interval. ${ }^{16}$ The antiarrhythmic agents flecainide and disopyramide are effective in blocking retrograde conduction in patients with pacemakers ${ }^{17}{ }^{18}$ and may ameliorate pacemaker syndrome. Nevertheless, flecainide increases the pacing threshold and requires careful control of pacemaker output. Patients who do not respond to these measures must be upgraded to dual chamber pacing. In new patients who require pacing but retain antegrade conduction and have preserved retrograde conduction the syndrome may be prevented by implantation of a dual chamber pacemaker.

Rose ANNE KenNy Research fellow

RICHARD SUTTON Consultant cardiologist

Cardiology Department,

Westminster Hospital,

London SW1P 2AP

Correspondence to: Dr Rose Anne Kenny.

1 Feruglio GA, Steinbach K. Pacing in the world today. World survey on cardiac pacing for the years 1979 to 1981. In: Feruglio GA, ed. Proceedings of the second European symposium on cardiac pacing. Padua: Piccin Medical, 1982:953-67.
2 Naito M, Dreifus LS, David D, Michelson EL, Mardelli TJ, Kmetzo JJ. Re-evaluation of the role of atrial systole to cardiac hemodynamics: evidence for pulmonary venous regurgitation during abnormal atrioventricular sequencing. Am Heart $\mathcal{F}$ 1983;105:295-302.

3 Naito M, Dreifus LS, Mardelli TJ, et al. Echocardiographic features of atrioventricular and ventriculoatrial conduction. Am f Cardiol 1980;46:625-33.

4 Enlebacher JA, Danner RL, Stelzel PE. Hypotension with ventricular pacing: an atrial vasodepresser reflex in human beings. $\mathcal{F}$ Am Coll Cardiol 1984;5:500-5.

Nishimar RA, Gersh BJ, Vlietstra RE, Osborn MJ, Ilstrup DM, Holmes DR. Hemodynamic and symptomatic consequences of ventricular pacing. PACE 1982;5:903-10.

6 Torresani J, Ebogosti A, Allard-Latour G. Pacemaker syndrome with DDD pacing. PACE 1984 7:1148-51.

7 Haas JM, Strait GB. Pacemaker induced cardiovascular failure: hemodynamic and angiographic observations. Am 7 Cardiol 1977;33:295-9.

8 Kruse I, Arnham K, Conradson TB, Ryden L. A comparison of the acute and long-term haemodynamic effects of ventricular inhibited and atrial synchronous ventricular inhibited pacing. Circulation 1982;5:846-55.

Perrins EJ, Morley CA, Chan SL, Sutton R. Randomised controlled trial of physiological and Perrins EJ, Morley CA, Chan SL, Sutton R. R
ventricular pacing. Br Heart 7 1983;50:112-7.

10 Sutton R, Perrins EJ, Morley C, Chan SL. Sustained improvement in exercise tolerance following physiological cardiac pacing. Eur Heart $\mathcal{f} 1983 ; 4: 781-5$.

1 Mitsuoka T, Kenny RA, Yeung TA, Chan SL, Perrins EJ, Sutton R. Benefits of DDD pacing in sick sinus syndrome. PACE 1985;8:293.

2 Kenny RA, Ingram A, Mitsuoka T, Walsh K, Sutton R. Optimal pacing mode for angina pectoris patients. Br Hearl $\mathcal{F}$ (in press).

3 Morley C, Sutton R, Perrins J, Chan SL. The importance of retrograde atrioventricular conduction in physiological cardiac pacing. In: Feruglio GA, ed. Proceedings of the second European symposium on cardiac pacing. Padua: Piccin Medical, 1982:739-41.

4 Madigan NP, Flaker GC, Curtis JJ, Reid J, Mueller KJ, Murphy TJ. Carotid sinus hypersensitivity: beneficial effects of dual chamber pacing. Am $\mathcal{f}$ Cardiol 1984;53:1034-50.

Morley CA, Perrins JP, Chan SL, McBrien DJ, Sutton R. Carotid sinus syncope. Analysis of persistent symptoms and role of atrioventricular sequential pacing. Br Heart 7 1982;47:411-8.

Morley CA Perrins EJ, Chan SL, Sutton R. The role of rate hysteresis pacing in the hypersensitive carotid sinus syndrome. PACE 1983;6:1224-8.

7 Perrins EJ, Morley CA, Dixey J, Sutton R. The pharmacological blockade of retrograde Pentricular conduction in paced patients.PACE 1983;6:A112.

8 Vardas $\mathrm{P}$, Kalogeropoulos $\mathrm{Ch}$, Kenny RA, Walsh K, Sutton R. The influence of disopyramide on sinus node function and atrioventricular conduction in syncopal patients [Abstract]. PACE 1986;9:310a.

\section{Weight gain in pregnancy: eating for two or just getting fat?}

What advice should a doctor give to a woman about her weight during pregnancy? Should he tell her to eat for two, or if she is gaining weight too fast should he advise her to diet? These are everyday questions, but, as so often happens, research has provided some conflicting answers.

The average woman gains $12.5 \mathrm{~kg}$ during pregnancy, though normal women may lose weight or gain over $20 \mathrm{~kg}$. ${ }^{1}$ Much of the increase is accounted for by the uterine contents, enlargement of maternal organs, and-particularly in the third trimester-increased body water. ${ }^{\prime}$ The remainder, averaging about $3.5 \mathrm{~kg}$, is fat. By a mechanism that is not fully understood ${ }^{2}$ pregnancy alters carbohydrate metabolism, ${ }^{3}$ and subcutaneous fat is laid down over the abdomen, back, and upper thighs, mainly in the first and second trimesters. ${ }^{13}$ The fat is usually lost again afterwards-a process aided by lactation ${ }^{4}$ - and for most women long term weight gain is an effect of age rather than parity. ${ }^{13}$ Nevertheless, during pregnancy fat women tend to put on more weight than thin ones. ${ }^{3}$

Women who are overweight at the start of pregnancy face an increased risk of complications. ${ }^{3}{ }^{6}$ Hypertensive disorders are more frequent,,$^{78}$ though the incidence in different reports varies widely-from $7 \%{ }^{9}$ to $46 \% .^{3}{ }^{10}$ Abnormal glucose tolerance is also more common, affecting $7-17 \%$ of obese women. ${ }^{7 \cdot 10}$ Increased risks of urinary tract infections and possibly thrombophlebitis have been reported, ${ }^{8}$ but the risks of anaemia ${ }^{8}$ and preterm delivery ${ }^{11}$ may be lower than in underweight women. Older studies found that perinatal mortality was higher among obese women, ${ }^{312}$ but more recent reports have not confirmed this ${ }^{7}{ }^{10}$; perinatal mortality may have been reduced in these patients because of recognition of the risks and consequent careful supervision. ${ }^{6}$ A recent American study concluded, however, that if 
antenatal complications develop in an obese woman she is at greater risk of losing her baby than a woman of normal weight with the same complication, though if there are no antepartum complications maternal weight does not alter perinatal mortality. ${ }^{8}$

Obese women tend to have large babies. ${ }^{6-11}$ They might therefore be expected to have increased risks of cephalopelvic disproportion, shoulder dystocia, and caesarean section, but the evidence on this question is not clear. " Some studies have reported increased rates of caesarean section, ${ }^{8} 11$ but others have not. ${ }^{70}$ When operative intervention is required, however, there is increased morbidity and wound infection. ${ }^{71}$ Among normal women the baby's birth weight is related both to the mother's weight before pregnancy ${ }^{13}{ }^{14}$ and to her weight gain during pregnancy, ${ }^{13}{ }^{15}$ but among severely overweight women the birth weight is related only to the weight before pregnancy and is not influenced by weight gain. ${ }^{13}$ The mother's weight also affects the baby's growth after birth: both normal ${ }^{7}$ and low birthweight ${ }^{16}$ babies put on weight more quickly if their mother is fat than if she is underweight. Whether this is due to genetic or intrauterine factors or to differences in later feeding patterns is unknown.

To what extent can obstetric risks be modified by dietary adjustment in pregnancy? Pregnant women are traditionally urged to eat for two, and concern has been expressed that enthusiasm for slimming may adversely affect fetal growth. ${ }^{17}$ Encouraging non-obese women to achieve an "appropriate" weight gain ${ }^{18}$ reduces the proportion of low birthweight babies, ${ }^{19}$ and in developing countries women may be given energy supplements for this purpose, though recently doubt has been cast on the need for such supplementation in the absence of obvious food shortages. ${ }^{201}{ }^{21}$ Nevertheless, there is little evidence that perinatal mortality can be improved by dietary measures aimed at increasing birth weight.

Recommendations for a minimum weight gain in pregnancy should take account of the weight before pregnancy: underweight women need to gain more than overweight women. ${ }^{22-24}$ If, then, there is no need to encourage fat women to gain weight in pregnancy ${ }^{13}$ should they be encouraged to lose weight? Dietary restriction for women who gain a lot of weight can reduce the birth weight of their babies, but once again there is no evidence that this reduces the risk of pregnancy complications. ${ }^{12}$ A Scottish study ${ }^{12}$ has concluded that "dietary restriction cannot be advocated even in the obese primigravida as it is possibly detrimental to the baby and of no benefit to the mother: it is probably better to try and reduce the obese woman's weight either before or after the pregnancy."

Senior Lecturer in Obstetrics and Gynaecology,

JAMES OWEN DRIFE

Royal Infirmary,

Leicester LE2 7LX

1 Hytten FE. Weight gain in pregnancy. In: Hytten FE, Chamberlain G, eds. Clinical physiology in obstetrics. Oxford: Blackwell, 1980:193-233.

2 Lind T. Carbohydrate metabolism. In: Hytten FE, Chamberlain G, eds. Clinical physiology in obstetrics. Oxford: Blackwell, 1980:234-56.

3 Gillmer MDG. Obesity in pregnancy-clinical and metabolic effects. In: Campbell DM, Gillmer MDG, eds. Nutrition in pregnancy: proceedings of the tenth study group of the Royal College of Obstetricians and Gynaecologists. London: RCOG, 1983:213-30.

4 McCann MF, Liskin LS, Piotrow PT, Rinehart W, Fox G. Breast-feeding, fertility, and family planning. Population Reports 1981;9: J-525-75.

Jelliffe DB, Jelliffe EFP. The volume and composition of human milk in poorly nourished communities: a review. Am $\mathcal{J}$ Clin Nutr 1978;31:492-515.

6 Friedman $\mathrm{CI}, \mathrm{Kim} \mathrm{MH}$. Obesity and its effect on reproductive function. Clin Obstet Gynecol $1985 ; 28: 645-63$

7 Edwards LE, Dickes WF, Alton IR, Hakanson EY. Pregnancy in the massively obese: course, outcome, and obesity prognosis of the infant. Am $\mathcal{f}$ Obstet Gynecol 1978;131:479-83.

Garbaciak JA, Richter M, Miller S, Barton JJ. Maternal weight and pregnancy complications. Am J Obstet Gynecol 1985;152:238-45.

9 Gross T, Sokol RJ, King KC. Obesity in pregnancy: risks and outcome. Obstet Gynecol 1980;56:446-50.

10 Calandra C, Abell DA, Beischer NA. Maternal obesity in pregnancy. Obstet Gynecol 1981;57:8-12.

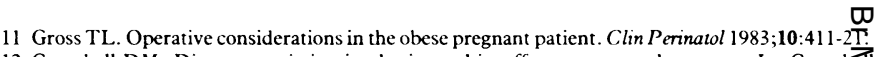
2 Campbell DM. Dietary restriction in obesity and its effect on neonatal outcome. In: Campbu DM, Gillmer MDG, eds. Nutrition in pregnancy: proceedings of the tenth study group of the Rog College of Obstetricians and Gynaecologists. London: RCOG, 1983:243-50.

13 Abrams BF, Laros RK. Pregnancy weight, weight gain, and birth weight. Am 7 Obstet Gyneco 1986;154:503-9.

4 Garn SM, Pesick SD. Relationship between various maternal body mass measures and size of newborn. Am f Clin Nutr 1982;36:664-8.

15 Knopp RH, Bergelin RO, Wahl PW, Walden CE. Relationships of infant birth size to mater lipoproteins, apoproteins, fuels, hormones, clinical chemistries, and body weight at 36 weesss gestation. Diabetes 1985;34 (suppl 2):71-75

16 Garn SM, LaVelle M. Interaction between maternal size and birth size and subsequent weiget gain. Am J Clin Nutr 1984;40:1120-1.

17 Palmer JL, Jennings GE, Massey L. Development of an assessment form: attitude toward weigh Palmer JL, Jennings GE, Massey L. Development of an ass

18 Loris P, Dewey KG, Poirier-Brode K. Weight gain and dietary intake of pregnant teenagers. I Dietet Assoc 1985;85:1296-1305

19 Orstead C, Arrington D, Kamath SK, Olson R, Kohrs MB. Efficacy of prenatal nutrit counselling: weight gain, infant birth weight, and cost-effectiveness. $\mathscr{7}$ Am Dietet Assoc $19 \overline{85}$ $85: 40-5$.

20 Briend A. Do maternal energy reserves limit fetal growth? Lancet $1985 ; \mathrm{i}: 38-40$

21 Campbell-Brown M, McFadyen IR. Maternal energy reserves and birthweight. Lancet 198 \&

Rosso P. A new chart to monitor weight gain during pregnancy. Am 7 Clin Nutr 1985;41:644-5z 23 Brown JE, Jacobson HN, Askue LH, Peick MG. Influence of pregnancy weight gain on the size infants born to underweight women. Obstet Gynecol 1981;57:13-7.

24 Naeye RL. Weight gain and the outcome of pregnancy. Am J Obstet Gynecol 1979;135:3-9.

\section{Licensed to kill}

About $5-10 \%$ of human peripheral white blood cells spont neously and rapidly kill in vitro a wide range of cultured ce\# lines, tumour cells, and virus infected cells. These naturat killer cells were described more than 10 years ago, and the are becoming of interest in several of the clinical medic specialties. As well as being an important component of natural resistance to infection, they may also play a part limiting the growth and metastatic spread of some tumours and in graft versus host disease. They may even prove to bo useful in treating some tumours.

Natural killer cells are large, low density lymphocyte rich in azurophillic cytoplasmic granules, that can be isolat by density gradient centrifugation from peripheral bloo They are also found in lymphoid tissues and may be detected in inflammatory sites. ${ }^{1}$ Natural killer cells isolated from peripheral blood lymphocytes are non-phagocytic, do ne bear surface immunoglobulin, and, in contrast to $T$ lymph cytes, do not require products of the HLA locus either for their activation or to recognise target cells. Although severg⿵ pan natural killer markers have been described-(fut. example, those recognised by the monoclonal antibodi B73- $1^{2}$ and Leu $11 a^{3}$ - the operational definition of natura killer cells is still based on their cytotoxic activity. They areg heterogeneous population and therefore cannot yet be givenno single phenotype relating to their function.

Although derived from bone marrow, the lineage 영 natural killer cells remains controversial. They can express phenotypic markers of myelomonocytic as well as of $\mathrm{T}$ cen origin. ${ }^{4}$ Most can form rosettes with sheep red blood celle and many of these can also express the Ml marker (mon\& clonal antibody defined monocyte-macrophage antigen The CD3 antigen, which is associated with the antigen recognition site of $\mathrm{T}$ lymphocytes, is found on a subset oP natural killer cells although they use a target recognition mechanism distinct from that used by cytotoxic T cells. ${ }^{5}$ Th phenotypic heterogeneity may reflect differences in the sta民 of differentiation or ontogeny of natural killer cells. Natura killer effectors recognise glycosylated structures on targê cell membranes by as yet undefined receptors. ${ }^{6}$ It was thought that developing techniques for culturing and cloniris natural killer effector cells would allow them to be more 